\title{
Global Media Framing of a Diplomatic Rift in the Middle East
}

\author{
By John Mark King* \\ Meruyert King ${ }^{\dagger}$
}

\begin{abstract}
Researchers performed a quantitative content analysis of a random sample of 389 newspaper and news agency headlines about a diplomatic rift in the Middle East published June 5-11, 2017 in 80 different English language newspapers from 34 nations. The theoretical underpinning was media framing theory, with a focus on emphasis framing, rooted in sociological research, which examines the content of communication. Independent variables were the nation and region of the world in which the headline was published and alignment, non-alignment or neutrality with the nation at the center of the rift, Qatar. Dependent variables were headline tone toward Qatar and headline topics/frames. Results showed that newspapers and news agencies tended to follow the lead of their respective national governments in headlines about the diplomatic rift among Qatar and four Arab nations (Saudi Arabia, Egypt, United Arab Emirates and Bahrain) that simultaneously severed diplomatic ties with Qatar. Headlines published in nations non-aligned with Qatar were the most negative (82.3\%) and the least positive (13.3\%). Headlines published in nations aligned with Qatar were the most positive (37.5\%) and least negative (50.0\%). Newspaper headlines published in nations that were neutral were $18.1 \%$ positive in tone. These differences were statistically significant at $<0.001$ level of probability. Overall, $71.2 \%$ of the headlines were negative in tone; $21.1 \%$ were positive, and $7.7 \%$ were neutral. The most frequent headline topics were the severing of diplomatic relations by four Arab nations with Qatar, a flight ban on Qatar Airways, US President Donald Trump criticizing Qatar and the crisis itself.
\end{abstract}

Keywords: diplomatic relations, diplomatic rift, media framing, Middle East, Qatar.

\section{Introduction}

On June 5, 2017, four Arab nations (Saudi Arabia, Egypt, United Arab Emirates and Bahrain) simultaneously cut all diplomatic ties with Qatar over their assessment that Qatar was supporting terrorist organizations. The New York Times headline and lead on June 5, 2017 summed it up: "Morning Agenda: 4 Mideast Countries Sever Ties to Qatar. Bahrain, Egypt, Saudi Arabia and the United Arab Emirates have severed diplomatic ties with Qatar, accusing it of fueling extremism and terrorism" (Chong, 2017). The Qatar government denied it had supported terrorist organizations, as the Qatar Tribune headline and lead reported: "Qatar rejects Saudi-led bloc's 'terror' list. Qatar on Friday rejected allegations of supporting individuals and groups blacklisted as 'terrorists' by four Arab countries which cut ties with it this week amid a major diplomatic fallout."

\footnotetext{
*Professor, American University of Sharjah, United Arab Emirates.

${ }^{\dagger}$ American University of Sharjah, United Arab Emirates.

${ }^{1}$ Qatar rejects Saudi-led bloc's "terror" list. Qatar Tribune, June 9, 2017. Retrieved from http:// www.lexisnexis.com/lnacui2api/api/version1/getDocCui?lni=5NRR-4VW1-F11P-X4DC\&csi= 270944,270077,11059,8411\&hl=t\&hv=t\&hnsd=f\&hns=t\&hgn=t\&oc=00240\&perma=true.
} 
The response to this action was immediate and dramatic, as evidenced by a sampling of the headlines in the study:

"Arab nations cut off Qatar for terror aid" (Green, 2017).

"UAE Closes Airspace to Qatar Flights as Gulf Spat Intensifies" (Yousefe, 2017).

"UAE closes down Qatar Airways offices inside its borders" (Sahoo, 2017).

"Hundreds of Pakistani pilgrims stranded on Doha airport following Qatar flight ban."

"Do not panic, embassy tells Indians in Qatar."

"Turkey to provide Qatar with food."

"Qatar negotiating water supplies with Turkey, Iran."

"Kidnapped while hunting; Qatar paid \$1 Billion to Jihadist to save Royal Family Members" (Khan, 2017).

"Trump slams Qatar; Tillerson voices support."6

"UAE to impose jail terms, fines for Qatar sympathizers."7

"It's 15 years in jail for Qatar sympathisers in UAE."

"Erdogan ratifies Turkish bill on Qatar troop deployment."

"FACING THE HEAT-Gulf tension can impact India's fuel import bill" (Dutta, 2017).

"QATAR'S 2022 WORLD CUP IN TURMOIL AS ANGER GROWS OVER LINKS TO TERROR" (Tozer, 2017).

\footnotetext{
${ }^{2}$ Hundreds of Pakistani pilgrims stranded on Doha airport following Qatar flight ban. Pakistan Today, June 7, 2017. Retrieved from http://www.lexisnexis.com/lnacui2api/api/version1/get DocCui?lni=5NR6-X4F1-JCH9-G0G7\&csi=270944,270077,11059,8411\&hl=t\&hv=t\&hnsd= $\mathrm{f} \&$ hns $=\mathrm{t} \& \mathrm{hgn}=\mathrm{t} \& \mathrm{oc}=00240 \&$ perma $=$ true.

${ }^{3}$ Do not panic, embassy tells Indians in Qatar. Times of India, June 9, 2017. Retrieved from http:// www.lexisnexis.com/lnacui2api/api/version1/getDocCui?lni=5NRN-41F1-DXJR-H34G\&csi $=270944,270077,11059,8411 \& h l=t \& h v=t \& h n s d=f \& h n s=t \& h g n=t \& o c=00240 \& p e r m a=t r u e$.

${ }^{4}$ Turkey to provide Qatar with food. Azer News, June 8, 2017. Retrieved from http://www.lexisne xis.com/lnacui2api/api/version1/getDocCui?lni=5NRH-3B41-F00C-6160\&csi=400868 \&hl=t\&hv= t\&hnsd=f\&hns=t\&hgn=t\&oc=00240\&perma=true.

${ }^{5}$ Qatar negotiating water supplies with Turkey, Iran. Azer News, June 7, 2017. Retrieved from http:// www.lexisnexis.com/lnacui2api/api/version1/getDocCui?lni=5NRD-WKD1-JCH9-G3 BK\&csi= $400868 \& h l=t \& h v=t \& h n s d=f \& h n s=t \& h g n=t \& o c=00240 \& p e r m a=t r u e$.

${ }^{6}$ Trump slams Qatar; Tillerson voices support. Chicago Daily Herald, June 10, 2017. Retrieved from http://www.lexisnexis.com//nacui2api/api/version1/getDocCui?lni=5NSG-75B1-DY6F-J0S3 \&csi=270944,270077,11059,8411\&hl=t\&hv=t\&hnsd=f\&hns=t\&hgn=t\&oc=00240\&perma=true . ${ }^{7} \mathrm{UAE}$ to impose jail terms, fines for Qatar sympathizers. Al Riyadh, June 7, 2017. Retrieved from http://www.lexisnexis.com/lnacui2api/api/version1/getDocCui?lni=5NRD-JCK1-JDJN-649W\& csi=270944,270077,11059,8411\&hl=t\&hv=t\&hnsd=f\&hns=t\&hgn=t\&oc=00240\&perma=true. ${ }^{8}$ It's 15 years in jail for Qatar sympathisers in UAE. Daily Nation, June 7, 2017. Retrieved from http://www.lexisnexis.com/lnacui2api/api/version1/getDocCui?lni=5NR8-JHM1-F11P-X1SD\&csi $=270944,270077,11059,8411 \& \mathrm{hl}=t \& h v=t \& h n s d=f \& h n s=t \& h g n=t \& o c=00240 \& p e r m a=t r u e$.

${ }^{9}$ Erdogan ratifies Turkish bill on Qatar troop deployment. Intellinews-MENA Today, June 9, 2017. Retrieved from http://www.lexisnexis.com/lnacui2api/api/version1/getDocCui?lni=5NRN- N4P1F15C-G542\&csi=270944,270077,11059,8411\&hl=t\&hv=t\&hnsd=f\&hns=t\&hgn=t\&oc=00240 \&perma=true.
} 


\section{Literature Review}

This diplomatic rift in the Middle East presented an opportunity to examine media framing theory in the early stages of a developing political crisis. Media framing studies have undertaken a multitude of perspectives and methodologies. In an analysis of framing research, Cacciatore, Scheufele and Iyengar called for differentiation between emphasis and equivalence framing (Cacciatore, Scheufele, and Iyengar, 2016). Equivalence framing focuses on the presentation of logically equivalent information. Emphasis framing focuses on the content of communication.

Unlike the equivalence-based definition of framing, this sociologically rooted definition moves framing outside of the presentation of logically equivalent information and into territory where the selection of one set of facts or arguments over another can be deemed a frame. As a result, more leeway is granted to the framing definition in the sociological tradition, with studies often manipulating what an audience receives rather than how equivalent information is presented. As work in this vein often involves emphasizing one set of considerations over another, this sociologically oriented approach to framing has been labeled "emphasis framing" (Cacciatore, et al., 2016, p. 10).

In the present study, media framing was basically conceptualized as emphasis framing, but in a naturally occurring setting (publication), rather than a manipulated experimental setting. Any variance measured was a result of the topics or frames newspapers and news agencies chose to use in headlines about the diplomatic rift.

Entman, one of the most influential scholars on media framing, arrived at an overarching conclusion on media framing theory.

I do think it reasonable to suggest that when news clearly slants, those officials favored by the slant become more powerful, freer to do what they want without the anticipation that voters might punish them. And those who lose the framing contest become weaker, less free to do (or say) what they want (Entman, 2007, p. 170).

Scheufele outlined the basics of the theoretical model, which posits that the way media frame topics has an impact on news consumers' understanding of the topic (Scheufele, 1999).

Recent international media framing research has focused on a myriad of topics and nations. Relevant, selected recent papers are reviewed here. A study of media framing of Korean-Japanese territorial disputes found that four news agencies framed the issue differently depending upon the nation of origin (Jang, and Frederick, 2017).

...The fact that this study found differences in the way news agencies from different countries framed the issue would lead one to believe that the way the media frame an issue is influenced by the dominant political ideology and national interests in which journalists operate and by the influences of government propaganda or public diplomacy (Jang, and Frederick, 2017, p. 226). 
Media framing research on New York Times coverage of two similar army takeovers of Palestinian refugee camps to remove militants, one in the West Bank and one in Lebanon, found that the two conflicts were framed much differently, despite many similar circumstances (Evans, 2010).

An analysis of television coverage by US-based CNN and Qatar-based AlJazeera of the overthrow of Egyptian president-elect, Mohamed Morsi by the Egyptian army found that CNN framed the event initially as a crisis and later as a coup, while AlJazeera's dominant frames of the event were as national division and a crisis (Martin, 2016).

A study of media framing comparing AlJazeera English and the AlJazeera Arabic television services in a random sample of 400 stories from more than 200 major world newspapers published from 2005-2007 found that tones were more frequently positive toward AlJazeera English (35.3\%) than the Arabic AlJazeera channel (11.9\%). Newspapers published in North America and Israel were the most negative toward AlJazeera (30.9\%). The Arabic service (11.4\%) was framed as associated with terrorism more frequently than the English channel (6.0\%) (King, and Zayani, 2008).

Media frames of drone strikes in Pakistan were analyzed in coverage by the New York Times, a dominant United States newspaper and News International, a Pakistani newspaper. Researchers concluded the Times framed drone strikes in Pakistan using positive tones, in step with the United States government, while the Pakistani newspaper used more negative tones, in opposition to the Pakistani government (Dar, and Ali, 2015).

Media framing has been seen in visual coverage as well as text. In an analysis of photographic coverage in news and public interest magazines of the conflict in Syria covering the period 2011-2012, researchers found that the majority of images, 80 percent, were displayed in war frames rather than peace frames, based on how the subject of the photograph was depicted (Greenwood, and Jenkins, 2015).

A media framing study of coverage of the disappearance of Malaysian Airlines flight 370 by researchers at the University of Tennessee found that the New Straits Times, the dominant Malaysian newspaper and China Daily framed the crisis differently. The Malaysian newspaper framed it as attribution of responsibility, human interest, morality and economic consequences in order of frequency. The Chinese English language newspaper framed the crisis as attribution of responsibility, human interest, economic consequences, conflict and morality (Park, Bier, and Palenchar, 2016). The authors drew on conclusions by previous researchers that the media system operating within the nation has a bearing on media framing (Valentini, and Romenti, 2011). National interests have also been found to influence framing by the media (Shoemaker, and Reese, 1996). The present study builds upon this knowledge. 


\section{Hypotheses and Research Questions}

The following research questions and hypotheses were informed by the previous literature review.

H1: The overall tone of headlines published about Qatar will be more negative than positive or neutral.

H2: Headlines published about Qatar in nations non-aligned with Qatar will more frequently display a negative tone toward Qatar than headlines published in nations aligned with Qatar and neutral nations.

H3: Headlines published about Qatar in western regions of the world (North America, South America, Europe and Australia/New Zealand) will more frequently display a negative tone toward Qatar than headlines published about Qatar in eastern regions of the world (Asia, Africa and the Middle East).

RQ1: What will be the most frequent headline topics in stories published about Qatar?

RQ2: How will headline topics differ in stories published about Qatar in nations aligned with Qatar compared to headline topics published in nations non-aligned with Qatar and neutral nations?

RQ3: How will headline topics differ in stories published about Qatar in western regions of the world (North America, South America, Europe and Australia/New Zealand) compared to headline topics published in eastern regions of the world (Asia, Africa and the Middle East)?

\section{Methodology}

A population of 752 newspaper or news agency stories with headlines published during the week of June 5-11, 2017 from the Lexis/Nexis database was generated using the search term "Qatar". A simple random sample of 400 stories with headlines was generated from this population using a random sample generator. Eleven stories that were exact duplicates were eliminated, leaving a total sample size of 389 newspaper or news agency stories and their associated headlines about a diplomatic rift in the Middle East published in 80 different English language newspapers from 34 nations across the world. Qatar was the nation at the center of the rift. Statistical significance was set at the 0.05 level. A limitation was that only headlines from English language newspapers and news agencies were analyzed.

The units of analysis were any headlines published about Qatar during the time period of the study. Two researchers performed a systematic, quantitative content analysis of the random sample of headlines. Intercoder reliability was $100 \%$ on each variable, except for tone toward Qatar, which had $98.3 \%$ agreement. Independent variables were nation in which the newspaper was published, region in which the newspaper was published (North America, South America, Europe, 
Asia, Middle East, Africa or Australia/New Zealand) and alignment, non-alignment or neutrality with Qatar. Region was collapsed for accurate statistical analysis. Region was collapsed to East/West (Asia, Middle East and Africa in the East) and (North America, South America, Europe and Australia/ New Zealand in the West).

Dependent variables were headline tone toward Qatar (positive, negative or neutral) and headline topics. Headline tone and headline topics were both collapsed to facilitate accurate statistical analysis.

An example of a negative headline tone was this one published in the Sun in England: "1,000 IRISH LIVING IN 'TERROR STATE'; 5 ARAB STATES SLAM QATAR" (Dineen, 2017). Conversely, a headline published by Pakistan Today was indicative of a positive tone. "Iran comes to Qatar's rescue, sends planes of food." 10

Neutral tones were only evident in the few headlines about Qatar published that were not related to the political rift. This headline, which announced a job opportunity by Siasat Daily in India was typical of neutral tones. "Hiring Computer System Engineer in Qatar". ${ }^{11}$ As noted previously the search term used for Lexis/Nexis was simply Qatar, so any stories about Qatar published during the first week of the crisis, the time period of the study, were included in the analysis.

Media framing theory, from the perspective of emphasis framing, was the theoretical underpinning. Media frames, were operationalized and based on the topics news organizations used to frame the diplomatic rift among Qatar, four Arab nations that simultaneously severed diplomatic relations with Qatar (Saudi Arabia, Egypt, United Arab Emirates and Bahrain) and news organizations in 29 other nations that published stories about the rift. Of interest was how newspapers and news agencies, particularly in nations were that diplomatically aligned with Qatar on non-aligned with Qatar, framed the topic of the diplomatic rift between Qatar and the four Arab nations. By measuring the differences in frequency and content of various topics presented in news coverage of the diplomatic rift, the researchers sought to test the impact of alignment or non-alignment with Qatar on the topics/frames used by the news organizations. For example, some headlines framed the story in terms of Qatar as a terrorist state, while other headlines framed the story in terms of food and water supply and safety of expats in Qatar.

While the topics of the headlines represented the frames, another dependent variable was the tone of the headline toward Qatar, the nation that was the object of the diplomatic rift. Previous research on Qatar, drawing on nation branding research, informed the methodology on measuring tone of the headlines (King, and Zayani, 2008).

\footnotetext{
${ }^{10}$ Iran comes to Qatar's rescue, sends planes of food. Pakistan Today, June 11, 2017. Retrieved from http://www.lexisnexis.com/lnacui2api/api/version1/getDocCui?ni=5NSB-SN21-JCH9-G3GH\&csi $=270944,270077,11059,8411 \& \mathrm{hl}=\mathrm{t} \& \mathrm{hv}=\mathrm{t} \& \mathrm{hnsd}=\mathrm{f} \& \mathrm{hns}=\mathrm{t} \& \mathrm{hgn}=\mathrm{t} \& \mathrm{oc}=00240 \&$ perma $=$ true .

${ }^{11}$ Hiring computer system engineer in Qatar. Siasat Daily, June 5, 2017. Retrieved from http:// www.lexisnexis.com/lnacui2api/api/version1/getDocCui?lni=5NPW-3DB1-F12F-F3YT\&csi=382 $623 \& \mathrm{hl}=\mathrm{t} \& \mathrm{hv}=\mathrm{t} \& \mathrm{hnsd}=\mathrm{f} \& \mathrm{hns}=\mathrm{t} \& \mathrm{hgn}=\mathrm{t} \& \mathrm{cc}=00240 \&$ perma $=$ true.
} 


\section{Results}

The following results were found using frequencies and chi-square tests as the appropriate data analysis warranted.

H1: The overall tone of headlines published about Qatar will be more negative than positive or neutral.

Table 1. Overall Tone of Headlines Published about Qatar

\begin{tabular}{|l|c|c|}
\hline Tone & Frequency & Percent \\
\hline Negative & 277 & 71.2 \\
\hline Positive & 82 & 21.1 \\
\hline Neutral & 30 & 7.7 \\
\hline
\end{tabular}

Note: $\mathrm{N}=389$.

As evidenced in Table 1, the overall the tone of headlines published about Qatar was strongly negative. A total of $71.2 \%$ were negative, $21.1 \%$ were positive. The hypothesis was supported.

H2: Headlines published about Qatar in nations non-aligned with Qatar will more frequently display a negative tone toward Qatar than headlines published in nations aligned with Qatar and neutral nations.

As seen in Table 2, headlines in the four Arab nations non-aligned with Qatar were strongly negative (UAE/94.1\%, Bahrain/91.7\%, Saudi Arabia/88.9\% and Egypt/77.8\%), as was the United States (73.8\%). Headlines in nations aligned with Qatar were less negative (Qatar itself/10.0\%, Iran/36.8\% and Pakistan/63.4\%). However, the one story published in Turkey was negative. Nations were collapsed into non-aligned with Qatar, aligned with Qatar and neutral to allow for accurate statistical analysis due to low frequency cells.

The hypothesis was supported at the $<0.001$ level. Headlines published in nations that were non-aligned with Qatar were overwhelmingly negative $(82.3 \%)$ and the least positive (13.3\%) as evidenced in Table 3. Headlines published in nations aligned with Qatar were the most positive $(37.5 \%)$ and least negative $(50.0 \%)$. Only $7.7 \%$ of the headlines were neutral in tone; the journalistic convention of neutrality appears to have been overtaken by the newspapers and news agencies alignment with their own governments at the outset of this diplomatic rift. 
Table 2. Nations by Headline Tone

\begin{tabular}{|c|c|c|c|}
\hline Nation & Negative & Neutral & Positive \\
\hline \multicolumn{4}{|c|}{ Non-aligned with Qatar } \\
\hline UAE & $94.1 \%$ & $0.0 \%$ & $5.9 \%$ \\
\hline Bahrain & $91.7 \%$ & $8.3 \%$ & $0.0 \%$ \\
\hline Saudi Arabia & $88.9 \%$ & $5.6 \%$ & $5.6 \%$ \\
\hline Egypt & $77.8 \%$ & $0.0 \%$ & $22.2 \%$ \\
\hline US & $73.8 \%$ & $4.8 \%$ & $21.4 \%$ \\
\hline \multicolumn{4}{|c|}{ Aligned with Qatar } \\
\hline Qatar & $10.0 \%$ & $20.0 \%$ & $70.0 \%$ \\
\hline Iran & $36.8 \%$ & $21.1 \%$ & $42.1 \%$ \\
\hline Pakistan & $63.4 \%$ & $7.3 \%$ & $29.3 \%$ \\
\hline Turkey & $100.0 \%$ & $0.0 \%$ & $0.0 \%$ \\
\hline \multicolumn{4}{|c|}{ Neutral Nations } \\
\hline Nigeria & $100.0 \%$ & $0.0 \%$ & $0.0 \%$ \\
\hline Malta & $100.0 \%$ & $0.0 \%$ & $0.0 \%$ \\
\hline Singapore & $100.0 \%$ & $0.0 \%$ & $0.0 \%$ \\
\hline Malaysia & $100.0 \%$ & $0.0 \%$ & $0.0 \%$ \\
\hline Lebanon & $100.0 \%$ & $0.0 \%$ & $0.0 \%$ \\
\hline Kuwait & $100.0 \%$ & $0.0 \%$ & $0.0 \%$ \\
\hline Jordan & $100.0 \%$ & $0.0 \%$ & $0.0 \%$ \\
\hline Canada & $100.0 \%$ & $0.0 \%$ & $0.0 \%$ \\
\hline Oman & $100.0 \%$ & $0.0 \%$ & $0.0 \%$ \\
\hline Australia & $89.5 \%$ & $5.3 \%$ & $5.3 \%$ \\
\hline South Africa & $87.5 \%$ & $12.5 \%$ & $0.0 \%$ \\
\hline UK & $86.5 \%$ & $1.9 \%$ & $11.5 \%$ \\
\hline Philippines & $75.0 \%$ & $0.0 \%$ & $25.0 \%$ \\
\hline India & $75.0 \%$ & $7.5 \%$ & $17.5 \%$ \\
\hline China & $75.0 \%$ & $0.0 \%$ & $25.0 \%$ \\
\hline New Zealand & $66.7 \%$ & $33.3 \%$ & $0.0 \%$ \\
\hline Thailand & $66.7 \%$ & $16.7 \%$ & $16.7 \%$ \\
\hline Kenya & $50.0 \%$ & $0.0 \%$ & $50.0 \%$ \\
\hline Azerbaijan & $39.1 \%$ & $13.0 \%$ & $47.8 \%$ \\
\hline Maldives & $33.3 \%$ & $0.0 \%$ & $66.7 \%$ \\
\hline Bangladesh & $0.0 \%$ & $0.0 \%$ & $100.0 \%$ \\
\hline Cyprus & $0.0 \%$ & $0.0 \%$ & $100.0 \%$ \\
\hline Sri Lanka & $0.0 \%$ & $0.0 \%$ & $100.0 \%$ \\
\hline Nepal & $0.0 \%$ & $100.0 \%$ & $0.0 \%$ \\
\hline Namibia & $0.0 \%$ & $100.0 \%$ & $0.0 \%$ \\
\hline Total & $71.2 \%$ & $7.7 \%$ & $21.1 \%$ \\
\hline
\end{tabular}

Note: $\mathrm{N}=389$.

Table 3. Alignment by Headline Tone

\begin{tabular}{|l|c|c|c|}
\hline Alignment & Negative & Neutral & Positive \\
\hline Neutral & $140 / 74.5 \%$ & $14 / 7.4 \%$ & $34 / 18.1 \%$ \\
\hline Aligned with Qatar & $44 / 50.0 \%$ & $11 / 12.5 \%$ & $33 / 37.5 \%$ \\
\hline Non-aligned with Qatar & $93 / 82.3 \%$ & $5 / 4.4 \%$ & $15 / 13.3 \%$ \\
\hline Total & $\mathbf{2 7 7 / 7 1 . 2 \%}$ & $\mathbf{3 0 / 7 . 7 \%}$ & $\mathbf{8 2} / \mathbf{2 1 . 1 \%}$ \\
\hline
\end{tabular}

Note: $\mathrm{N}=389 ; \mathrm{x}^{2}=27.3 ; \mathrm{df}=4 ; \mathrm{p}<0.001$. 
H3: Headlines published about Qatar in western regions of the world (North America, South America, Europe and Australia/New Zealand) will more frequently display a negative tone toward Qatar than headlines published about Qatar in eastern regions of the world (Asia, Africa and the Middle East).

Table 4. Region of the World by Tone

\begin{tabular}{|l|c|c|c|}
\hline Region of the world & Negative & Neutral & Positive \\
\hline East & $168 / 65.6 \%$ & $23 / 9.0 \%$ & $65 / 25.4 \%$ \\
\hline West & $109 / 82.0 \%$ & $7 / 5.3 \%$ & $17 / 12.8 \%$ \\
\hline Total & $277 / 71.2 \%$ & $30 / 7.7 \%$ & $82 / 21.1 \%$ \\
\hline
\end{tabular}

Note: $\mathrm{N}=389 ; \mathrm{x}^{2}=11.5 ; \mathrm{df}=2 ; \mathrm{p}<0.01$.

The hypothesis is supported at the $<0.01$ level as shown in Table 4. Headlines published about Qatar in western regions of the world (North America, South America, Europe and Australia/New Zealand) were more frequently negative $(82.0 \%)$ than headlines published about Qatar in eastern regions of the world (Asia, Africa and the Middle East) at $65.6 \%$ negative. Headlines published in the East $(25.4 \%)$ were almost twice as positive as headlines published in the West $(12.8 \%)$.

RQ1: What will be the most frequent headline topics in stories published about Qatar?

Table 5. Headline Topics in Stories Published about Qatar

\begin{tabular}{|l|c|c|}
\hline Headline topic & Frequencv & Percent \\
\hline 4 Arab nations sever ties & 28 & 7.2 \\
\hline Flight ban & 17 & 4.4 \\
\hline Trump slams & 14 & 3.6 \\
\hline Crisis & 11 & 2.8 \\
\hline No flight ban & 11 & 2.8 \\
\hline Crisis solving & 10 & 2.6 \\
\hline Saudi severs ties & 10 & 2.6 \\
\hline Indian safety & 7 & 1.8 \\
\hline Oil prices up & 7 & 1.8 \\
\hline Pakistan no sever ties & 7 & 1.8 \\
\hline Other nations sever ties & 7 & 1.8 \\
\hline UAE iail threat & 7 & 1.8 \\
\hline Kuwait crisis solving & 6 & 1.5 \\
\hline Turkey support & 6 & 1.5 \\
\hline Joint Investigation letter & 5 & 1.3 \\
\hline Pakistan stranded fliers & 5 & 1.3 \\
\hline Oatar financial loss & 5 & 1.3 \\
\hline US crisis solving & 5 & 1.3 \\
\hline AlJazeera cvber attack & 4 & 1.0 \\
\hline Bahrain severs ties & 4 & 1.0 \\
\hline Stock loss & 4 & 1.0 \\
\hline Trump offers & 4 & 1.0 \\
\hline Turkey military support & 4 & 1.0 \\
\hline FIFA World Cup & 4 & 1.0 \\
\hline Note: N 389(tuncated & & \\
\hline
\end{tabular}

Note: $\mathrm{N}=389$ (truncated table).

Table 5 includes headline topics with frequencies of four or more. The most frequent headline topic (28/7.2\%) was the four Arab nations (Saudi Arabia, Egypt, United Arab Emirates and Bahrain) that simultaneously cut diplomatic ties with 
Qatar. The flight ban imposed on Qatar Airways or flight bans imposed on some other airlines flying into Qatar was the second most frequent headline topic (17/4.4\%), followed by US President Donald Trump slamming Qatar (14/3.6\%). There were a total of 171 headline topics overall.

Table 6. Headline Topics in Stories Published about Qatar (Collapsed)

\begin{tabular}{|l|c|c|}
\hline Headline topic & Frequency & Percent \\
\hline 4 Arab nations sever ties/sever ties/flight ban/jail threat & 128 & 32.9 \\
\hline Other & 43 & 11.1 \\
\hline No server ties/no flight ban/Turkey support & 42 & 10.8 \\
\hline Terror/crisis & 40 & 10.3 \\
\hline Crisis solving & 37 & 9.5 \\
\hline Stranded expats/expat safety/human rights/water food supply & 32 & 8.2 \\
\hline Financial loss & 25 & 6.4 \\
\hline Oil/LNG & 21 & 5.4 \\
\hline Trump & 21 & 5.4 \\
\hline
\end{tabular}

Note: $\mathrm{N}=389$.

In Table 6, all 171 topics have been collapsed to provide a better picture of the topic categories. Interestingly, topics that can be seen as negative toward Qatar (four Arab nations server ties/other nations server ties/flight ban and jail threat) were more frequent $(128 / 32.9 \%)$ than topics seen as positive toward Qatar (nations not severing ties, nations with no flight ban and Turkey support), with 42/10.8\%. The large other category is due to topics with low frequencies that did not fit into the eight categories.

RQ2: How will headline topics differ in stories published about Qatar in nations aligned with Qatar compared to headline topics published in nations non-aligned with Qatar and neutral nations?

Table 7. Alignment by Headline Topic

\begin{tabular}{|l|c|c|c|c|}
\hline Topics & Neutral & $\begin{array}{c}\text { Aligned with } \\
\text { Qatar }\end{array}$ & $\begin{array}{c}\text { Non-aligned } \\
\text { with Qatar }\end{array}$ & Total \\
\hline $\begin{array}{l}\text { 4 Arab nations sever ties/other nations } \\
\text { sever ties/flight ban/jail threat }\end{array}$ & $27.1 \%$ & $21.6 \%$ & $51.3 \%$ & $\mathbf{3 2 . 9 \%}$ \\
\hline Crisis solving & $9.6 \%$ & $11.4 \%$ & $8.0 \%$ & $\mathbf{9 . 5 \%}$ \\
\hline Financial loss & $4.8 \%$ & $2.3 \%$ & $12.4 \%$ & $\mathbf{6 . 4 \%}$ \\
\hline $\begin{array}{l}\text { Nations do not sever ties/no flight } \\
\text { ban/Turkey support }\end{array}$ & $14.9 \%$ & $13.6 \%$ & $1.8 \%$ & $\mathbf{1 0 . 8 \%}$ \\
\hline Oil/LNG & $4.8 \%$ & $8.0 \%$ & $4.4 \%$ & $\mathbf{5 . 4 \%}$ \\
\hline Other & $12.2 \%$ & $15.9 \%$ & $5.3 \%$ & $\mathbf{1 1 . 1 \%}$ \\
\hline $\begin{array}{l}\text { Stranded expats/expat safety/ } \\
\text { human rights/water and food supply }\end{array}$ & $9.6 \%$ & $13.6 \%$ & $1.8 \%$ & $\mathbf{8 . 2 \%}$ \\
\hline Terror/crisis & $10.6 \%$ & $12.5 \%$ & $8.0 \%$ & $\mathbf{1 0 . 3 \%}$ \\
\hline Trump & $6.4 \%$ & $1.1 \%$ & $7.1 \%$ & $\mathbf{5 . 4 \%}$ \\
\hline
\end{tabular}

Note: $\mathrm{N}=389 ; \mathrm{x}^{2}=60.2 ; \mathrm{df}=19 ; \mathrm{p}<0.001$. 
Table 7, shows that headlines published in nations that were non-aligned with Qatar were more focused on the negative aspects and US President Donald Trump's bashing of Qatar, while headlines published in nations aligned with Qatar were more focused on positive aspects.

Headlines featuring negative topics toward Qatar (four Arab nations server ties, other nations sever ties, the flight ban against Qatar Airways in the four Arab nations and flight bans from those nations into Qatar and the threat of a 15-year jail sentence for anyone in Saudi Arabia, UAE or Bahrain who expressed support for Qatar) were more frequently published in nations non-aligned with Qatar (51.3\%) compared to headline topics published in nations aligned with Qatar $(21.6 \%)$. Conversely, more positive headline topics such as efforts to solve the crisis and nations that did not sever ties, nations that did not impose a flight ban on Qatar Airways and flights into Qatar from their respective nations and Turkey's strong support of Qatar were more frequently published in nations aligned with Qatar. Headline topics about wellbeing of expats stranded in Qatar, expat safety in Qatar, human rights and the water and food supply in Qatar were much more frequent in nations aligned with Qatar (13.6\%) compared to nations non-aligned with Qatar (1.8\%).

RQ3: How will headline topics differ in stories published about Qatar in western regions of the world (North America, South America, Europe and Australia/New Zealand) compared to headline topics published in eastern regions of the world (Asia, Africa and the Middle East)?

Table 8. Region of the World by Headline Topic

\begin{tabular}{|l|c|c|c|}
\hline Topics & East & West & Total \\
\hline $\begin{array}{l}\text { 4 Arab nations sever ties/other nations sever ties/flight } \\
\text { ban/jail threat }\end{array}$ & $31.3 \%$ & $36.1 \%$ & $\mathbf{3 2 . 9 \%}$ \\
\hline Crisis solving & $11.3 \%$ & $6.0 \%$ & $\mathbf{9 . 5 \%}$ \\
\hline Financial loss & $5.9 \%$ & $6.0 \%$ & $\mathbf{6 . 4 \%}$ \\
\hline Nations do not sever ties/no flight ban/Turkey support & $13.3 \%$ & $6.0 \%$ & $\mathbf{1 0 . 8 \%}$ \\
\hline Oil/LNG & $5.5 \%$ & $5.3 \%$ & $\mathbf{5 . 4 \%}$ \\
\hline Other & $10.2 \%$ & $12.8 \%$ & $\mathbf{1 1 . 1 \%}$ \\
\hline $\begin{array}{l}\text { Stranded expats/expat safety/human rights/water and food } \\
\text { supply }\end{array}$ & $10.5 \%$ & $3.8 \%$ & $\mathbf{8 . 2 \%}$ \\
\hline Terror/crisis & $9.4 \%$ & $12 \%$ & $\mathbf{1 0 . 3 \%}$ \\
\hline Trump & $2.7 \%$ & $10.5 \%$ & $\mathbf{5 . 4 \%}$ \\
\hline
\end{tabular}

Note: $\mathrm{N}=389 ; \mathrm{x}^{2}=23.8 ; \mathrm{df}=8 ; \mathrm{p}<0.01$.

As Table 8 demonstrates, headlines published in eastern regions of the world (Asia, Africa and the Middle East) more frequently than headlines published in western regions of the world (North America, South America, Europe and Australia/New Zealand) framed stories as crisis solving, nations that did not sever ties with Qatar/nations that did not impose flight bans/Turkey support and stranded expats/expat safety/human rights/water and food supply. On the other hand, headlines published in western regions of the world more frequently than headlines published in eastern regions of the world were about the four Arab 
nations severing ties with Qatar/other nations severing ties with Qatar/nations that did impose flight bans/the threat of jail for anyone supporting Qatar, terrorism/ crisis and US President Donald Trump's bashing of Qatar.

\section{Discussion}

The present study found strong support for the second hypothesis, that headlines published about Qatar in nations non-aligned with Qatar would more frequently display a negative tone toward Qatar than headlines published in nations aligned with Qatar and neutral nations.

Headlines published in nations non-aligned with Qatar were the most negative $(82.3 \%)$ and the least positive (13.3\%). Headlines published in nations aligned with Qatar were the most positive $(37.5 \%)$ and least negative $(50.0 \%)$. The hypothesis was supported at $<0.001$. To be sure, in some nations the media, news agencies and the government are strongly intertwined; this limitation may partially explain the outcome in the present study, as this is the case in Saudi Arabia, the United Arab Emirates, Bahrain, Qatar and Iran. But even in the United States and to some extent, Egypt, democratic nations with an independent press system, the pattern persisted. The implication here is that many newspapers and news agencies selected headline topics that fit the orientation of their national governments toward Qatar, rather than providing a balanced objective view of the diplomatic rift.

Hypotheses 1 and 3 were also supported. The tone of headlines published about Qatar was strongly negative $(71.2 \%)$ as predicted in Hypothesis 1 . In fact, tone was polarized with $21.1 \%$ positive and $7.7 \%$ neutral in tone toward Qatar, indicating that the journalistic convention of objectivity was not adhered to in this diplomatic rift. Hypothesis 3 was also supported strongly. Headlines published about Qatar in western regions of the world (North America, South America, Europe and Australia/New Zealand) did more frequently display a negative tone toward Qatar than headlines published about Qatar in eastern regions of the world (Asia, Africa and the Middle East) as predicted. The difference was $82.0 \%$ negative in the western regions and $65.6 \%$ negative in the eastern regions. Headlines in the East were more frequently positive (25.4\%) and neutral $(9.0 \%)$ than headlines in the West (12.8\% positive and 5.3\% neutral). Clearly newspapers and news agencies in the western regions of the world framed the diplomatic rift more negatively than in eastern regions.

This trend is also reflected in the framing analysis of headline topics. Headlines in nations non-aligned with Qatar more frequently framed the diplomatic rift by focusing on the negative aspects such as the four Arab nations severing ties with Qatar, other nations severing ties with Qatar, the flight ban on Qatar Airways and flights into Qatar from their respective nations and the 15-year jail threat for Qatar sympathizers; financial loss for Qatar and other nations; and US President Donald Trump's bashing of Qatar. On the other hand, headlines published in nations aligned with Qatar framed the diplomatic rift by more frequently focusing on more positive aspects such as efforts to solve the crisis, nations that did not 
sever ties with Qatar, nations that did not impose a flight ban on Qatar Airways and flights into Qatar from their respective nations and Turkey's strong support of Qatar. Headline topics about the well being of expats stranded in Qatar, expat safety in Qatar, human rights and the water and food supply in Qatar were much more frequent in nations aligned with Qatar than those nations non-aligned with Qatar.

Similar trends were seen in headline topics in regions of the world; headlines published in the West more frequently framed the diplomatic rift using the same negative focus, while headlines published in the East more frequently framed the diplomatic rift in positive terms. This is because no western nations aligned with Qatar, and the few nations that did align with Qatar were in the East.

\section{Conclusion}

This extensive analysis of newspaper and news agency coverage of the diplomatic rift in the Middle East in a large sample of newspaper headlines and stories published in 80 different English language newspapers from 34 nations across the world has provided important insights as outlined in the discussion.

Future research should focus on the significant finding here that newspaper and news agency headlines published in nations aligned or non-aligned with a nation at the center of the diplomatic rift followed the lead of their national governments in terms of media framing from an emphasis perspective and in terms of tone toward the nation. This is important, because it suggests possible media/government alignment on crucial diplomatic relations. If news organizations simply follow the lead of their respective governments rather than providing independent, balanced, objective coverage, citizens will be ill equipped to make rational decisions about diplomatic relations among nations. In the case of Qatar, the result in the first week of this diplomatic rift was confusion and uncertainty for expats and industries. Food and water supply, general safety and the state of work visas were primary concerns for expats in Qatar and Qatari expats in other nations. Airlines and oil/natural gas industries, as well as nations dependent on these industries, also faced upheaval and uncertainty.

Subsequent research should also focus on other media such as broadcast media, online media and social media as well as diplomatic rifts in other regions of the world. Controlling for media systems, media ownership and control of the media in various nations, all potential limitations to generalizability, may also prove useful.

\section{References}

Cacciatore, M., Scheufele, D. A., and Iyengar, S. (2016). The end of framing as we know it... and the future of media effects. Mass Communication and Society, 19, (2016), 723. 
Chong, S. (June 5, 2017). Morning agenda: 4 Mideast countries sever ties to Qatar. New York Times on the Web. Retrieved from https://nyti.ms/2s97hEj.

Dar, A., and Ali, S. (2015). How Pakistani and the US elite print media painted issue of drone attacks: Framing analysis of the News International and the New York Times. Global Media Journal: Pakistan Edition, 8(2), 1-17.

Dineen, K. (2017). 1,000 Irish living in "terror state"; 5 ARAB states slam Qatar. The Sun, June 6, 2017. Retrieved from http://www.lexisnexis.com/lnacui2api/api/version1/get DocCui?lni=5NR1-8TH1-JBVM-Y229\&csi=234674\&hl=t\&hv=t\&hnsd=f\&hns=t\& hgn $=$ t\&oc $=00240 \&$ perma $=$ true.

Dutta, S. (2017). Facing the heat-Gulf tension can impact India's fuel import bill. Times of India, June 6, 2017. Retrieved from http://www.lexisnexis.com/lnacui2api/api/ version1/getDocCui?lni=5NR1-6FR1-JB3N-T2X9\&csi=382891,362639\&hl=t\& $\mathrm{hv}=\mathrm{t} \& \mathrm{hnsd}=\mathrm{f} \& \mathrm{hns}=\mathrm{t} \& \mathrm{hgn}=\mathrm{t} \& \mathrm{oc}=00240 \&$ perma $=$ true.

Entman, R. (2007). Framing bias: Media in the distribution of power. Journal of Communication, 57(1), 163-173.

Evans, M. (2010). Framing international conflicts: Media coverage of fighting in the Middle East. International Journal of Media \& Cultural Politics, 6(2), 209-233.

Greene, L. (June 5, 2017). Arab nations cut off Qatar for terror aid. Daily News (New York). Retrieved from https://bit.ly/2yaLYFa.

Greenwood, K., and Jenkins, J. (2015). Visual framing of the Syrian conflict in news and public affairs magazines. Journalism Studies, 16(2), 207-227.

Jang, W. Y., and Frederick, E. (2017). International media framing: A case study of Korean-Japanese territorial disputes. Journal of Asian Pacific Communication, 27(2), 213-231.

Khan, S. (June 8, 2017). Kidnapped while hunting; Qatar paid \$1 billion to Jihadist to save royal family members. Free Press Journal. Retrieved from https://bit.ly/2BZ5Ei2.

King, J. M., and Zayani, M. (2008). Media, branding and controversy: Perceptions of Al Jazeera in newspapers around the world. Journal of Middle East Media, 4(1), 27-43.

Martin, E. (2016). Framing international media in the face of social movements: CNN and Al-Jazeera English in the fall of Morsi. Communication \& Society, 29(3), 119-130.

Park, S., Bier, L. M., and Palenchar, M. J. (2016). Framing a mystery: Information subsidies and media coverage of Malaysia Airlines flight 370. Public Relations Review, 4(2), 654-664.

Sahoo, S. (June 7, 2017). UAE closes down Qatar Airways offices inside its borders. The National. Retrieved from https://bit.ly/2wF76k3.

Scheufele, D. A. (1999). Framing as a theory of media effects. Journal of Communication, 49(1), 103-122.

Shoemaker, P. J., and Reese, S. D. (1996). Mediating the message: theories of influences on mass media content. London, UK: Longman.

Tozer, J. (2017). Qatar's 2022 world cup in turmoil as anger grows over links to terror. Daily Mail, June 6, 2017. Retrieved from https://bit.ly/2miHUuR.

Valentini, C., and Romenti, S. (2011). The press and Alitalia's 2008 crisis: Issues, tones, and frames. Public Relations Review, 37, 360-365.

Yousef, D. K. (June 8, 2017). UAE closes airspace to Qatar flights as Gulf spat intensifies. Las Cruces Sun-News. Retrieved from https://bit.ly/2LGpGhb. 